\title{
PENDIDIKAN AGAMA BERPARADIGMA INTEGRATIF DI SEKOLAH DASAR (PENDEKATAN HERMENEUTIS)
}

\author{
Yu'timaalahuyatazaka \\ Mahasiswa Program Pascasarjana UIN Sunan Kalijaga Yogyakarta \\ Email: yutimaalahuyatazaka@yahoo.com
}

\begin{abstract}
In article, the title is Integrative Paradigm of the Religion (Islamic) Education in Primary School (Hermeneutical Approach). It explains that Islamic education has to transform the paradigm from dicotomic-atomistic to integrative-interconective. The dicotomic-atomistic paradigm is splitting of religion and science, but the integrative-interconective paradigm is unification, with the result that it is suitable to contemporary Islamic Education. Accordingly, reconstruction to Islamic education is necessary to face the challenges of contemporary times in social and cultural issues. In article, Islamic education displays the patterns of global and local thought to hermeneutical method. Therefore, hermeneutics has to be required in approaching and reconstructing of Islamic education. How the hermeneutics uses the three entities in analyzing of Islamic education that are text (Islamic Education), context (Civics Education) and contextualization (local :home, school, community and global: state and nation). The three of entities are mutual dialectic, so that the integrativeinterconnective paradigm Islamic education is realized. Thereby, Islamic education can solve problems for contemporary life society in Indonesia.
\end{abstract}

Keywords: Islamic education, civics education, hermeneutics, local and global.

\section{Abstrak}

Artikel ini berjudul Pendidikan Agama Berparadigma Integratif di Sekolah Dasar (Pendekatan Hermeneutis). Artikel ini menjelaskan bahwa problem yang dialami dalam pendidikan Islam saat ini ialah problem dikotomik. Agama terpisah dari ilmu, begitupun sebaliknya. Sehingga, untuk mengatasi problem tersebut pendidikan Islam harus merubah paradigmanya dari dikotomik-atomistik menjadi integratif-interkonektif. Sehingga, paradigma integrasi ini sangat sesuai dengan realitas pendidikan Islam kontemporer dan mampu menjawab dan memecahkan problem-problem sosial dan budaya kekinian. Dengan metode hermeneutis ini pendidikan Islam terbagi menjadi dua konsep yaitu global dan lokal. Dalam proses inilah terjadi dialektika antara teks (pendidikan agama Islam), konteks (pendidikan kewarnegaraan), dan kontekstualisasi (konteks global: negara/bangsa, dan konteks lokal: keluarga, sekolah, dan masyarakat). Sehingga, pendidikan Islam dapat selalu menjawab dan memecahkan problematika kehidupan kontemporer umat.

Kata kunci: Pendidikan Agama (Islam), Pendidikan Kewarganegaraan, hermeneutika, konteks global dan lokal. 


\section{Pendahuluan}

Problematika yang melanda pendidikan Agama sekarang ini ialah problem pendidikan dikotomik. Agama terpisah dari ilmu, begitupun juga sebaliknya. Sehingga, perlu adanya pemecahan masalah dalam menangani keterpisahan antara agama dan ilmu. Sudah waktunya, agama tidak bisa mengklaim bahwa dirinya merupakan entitas tunggal yang mampu memberikan solusi terhadap berbagai kompleksitas kehidupan manusia. Begitu pun juga ilmu, sudah saatnya ilmu tidak bisa berdiri sendiri dalam memberikan kemajuan peradaban manusia. Agama membutuhkan ilmu, demikian juga sebaliknya. Agama menuntun ilmu agar dapat memberikan kemaslahatan umat, ilmu bekerjasama dengan agama agar dapat memecahkan problem kontemporer umat. Dengan demikian, diperlukan adanya pendidikan non-dikotomik yang menekankan adanya integrasi antara agama dan ilmu.

Diskursus integrasi agama dan ilmu menjadi obyek perbincangan di dunia akademik. Banyak para pemikir sekaligus akademisi concern terhadap wacana integrasi ilmu. Sehingga, munculah berbagai teori tentang integrasi ilmu dan agama seperti Islamisasi ilmu, Integralisasi Ilmu, hingga Integrasi-Interkoneksi ilmu. Dalam penulisan kali ini, akan dibahas mengenai salah satu dari ketiga integrasi ilmu tersebut, sekaligus sebagai paradigma yang tepat sebagai salah satu model aplikasi dalam pendidikan Agama di Sekolah Dasar. Model integrasi ilmu tidak lain dan tidak bukan merupakan model yang sekarang ini menjadi trend di berbagai perguruan tinggi, khususnya Perguruan Tinggi Agama Islam seperti (IAIN/UIN). Bagi sebagian Perguruan Tinggi tersebut proyek integrasi ilmu bukan lagi hanya sebatas sebagai wacana, melainkan sudah masuk pada tataran praksis-implementatifnya.

Apabila yang terjadi adalah integrasi antara ilmu dan agama, berarti bagaimana mengintegrasikan (memadukan, membenamkan, memasukkan, dan lain sebagainya) antara ilmu dan agama, ilmu dengan demikian tidak lepas dari agama. Agama pun demikian tidak bisa lepas dari ilmu. Entah itu ilmu apapun selalu terikat 
dengan agama. Pola demikian, bisa diasumsikan, bahwa bisa jadi ilmu pengetahuan umum-modern (sekular) harus ditanamkan agama di dalamnya, entah itu berupa etika, moral, nilai-nilai universal, atau bahkan hanya teksnya saja secara formallahiriahnya. Bisa jadi, apa yang disebut sebagai agama itu mengalami obyektivikasi, sehingga dapat bermanfaat bagi seluruh manusia. Atau, ilmu dan agama itu saling menyapa, bekerja sama, dan terkoneksi antara satu ilmu dengan ilmu yang lain sehingga di dalam ilmu-ilmu tersebut sudah secara otomatis terjalin integrasi untuk memecahkan problematika kekinian.

Di sini, penulis mencoba mengaplikasikan teori integrasi antara agama dan ilmu dalam upaya mengkonstruksi pendidikan Agama berbasis integratif di Sekolah Dasar. Jadi, pendidikan Agama sudah saatnya mengalami pergeseran paradigma (shifting paradigm) dari dikotomik-atomistik ke integratif-interkonektif keilmuan. Pedekatan yang penulis gunakan ialah pendekatan hermeneutika. Pendekatan ini lebih berorientasi pada aspek verstehen daripada erklaren. Berarti Pendidikan Agama melalui pendekatan hermeneutika dapat menyentuh, melihat, menyapa, dan melakukan tindakan yang tepat dalam mengatasi realitas kehidupan kontemporer. Pendidikan Agama yang berdasarkan pada teks, seharusnya sudah menyentuh pada aspek konteks dan kontekstualisasi. Dialektika antara teks, konteks, dan kontekstualisasi inilah yang akan mengkonstruk paradigma pendidikan Agama Integratif, yaitu pendidikan Agama yang berdialog dan berdialektika dengan realitas kehidupan kontemporer.

\section{Integrasi Ilmu dan Agama}

Agama dan sains dianggap sebagai konsep yang terpisah. Hal ini umumnya diyakini bahwa sains dan agama adalah dua bentuk yang saling bertentangan. Tidak ada satupun ilmuan yang memiliki niat dan mempertimbangkan secara serius dialog antara agama dan sains. Wahyu Tuhan dipisahkan dari ilmu.(Kasem Khaleel 2003: 5) Sampai-sampai sains dan agama keduanya menjadi retak, hampir-hampir dua hal 
tersebut sulit untuk didamaikan. Bahkan, agama pun dibuang ke wilayah keyakinan buta semata dan ritual-ritual menghibur sesaat yang dianggap kuno oleh sains. (Fethullah Gulen 2006: 17)

Menurut Holmes Rolston (1987:1), ada implikasi dari pandangan positivistik dan ilmiah yaitu mengagung-agungkan sains dan mengaggap rendah agama yang mengakibatkan kekeliruan pemahaman terhadap hakikat metode agama dan sains. Pada saat yang sama, dalam isi materinya, ilmu dan agama secara khusus menawarkan penafsiran pengalaman alternatif, penafsiran ilmiah didasarkan pada kausalitas, sedangkan penafsiran agama didasarkan pada makna.

Dengan demikian, diperlukan solusi terhadap retaknya hubungan antara agama dan ilmu, yaitu dengan integrasi keilmuan. Integrasi seperti yang diungkapkan oleh M. Amin Abdullah (2012:vii) ialah yakni dengan cara meleburkan dan melumatkan yang satu ke dalam yang lainnya, baik dengan cara meleburkan sisi normativitas-sakralitas keberagamaan secara menyeluruh masuk ke wilayah historisitas-profanitas, atau sebaliknya membenamkan dan meniadakan seluruhnya sisi historisitas kebergamaan Islam ke wilayah normativitas-sakralitas tanpa reserve (integrasi), dan interkoneksitas ialah setiap bangunan keilmuan apapun, baik keilmuan agama (termasuk agama Islam dan agama-agama yang lain), keilmuan sosial, humaniora, maupun kealaman tidak dapat berdiri sendiri. Paradigma interkoneksitas menurut Amin, yang lebih modest (mampu mengukur kemampuan diri sendiri), humility (rendah hati) dan human (manusiawi).

Sementara itu, menurut Naquib al-Attas, Islamisasi ilmu adalah upaya membebaskan ilmu pengetahuan dari makna, idiologi, dan prinsip-prinsip sekular, sehingga terbentuk ilmu pengetahuan baru yang sesuai fitrah Islam. Sementara itu, menurut Seyyed Hossein Nasr, Islamisasi ilmu berkenaan dengan perubahan ontologis dan epistemologis, terkait dengan cara pandang perubahan dunia yang merupakan dasar lahirnya ilmu dan metodologi yang digunakan, agar sesuai dengan konsep Islam. Sedangkan, menurut Al-Faruqi, islamisasi ilmu adalah mengislamkan 
disiplin-disiplin ilmu, atau lebih tepatnya menghasilkan buku-buku pegangan (buku dasar) di perguruan tinggi dengan menuangkan kembali disiplin-disiplin ilmu modern dalam wawasan Islam, setelah dilakukan kajian kritis terhadap kedua sistem pengetahuan, Islam dan Barat.(Khudori 2012: 240). Selain itu, menurut Al-Faruqi (1982: 14) bahwa, sudah seharusnya tidak ada lagi yang disebut sebagai "keraguan" bahwa para ilmuwan Muslim seharunya menguasai seluruh disiplin pengetahuan modern, memahaminya secara utuh, dan mencapai perintah mutlak terhadap semua yang mereka tawarkan. Inilah persyaratan pertama. Kemudian, para ilmuwan seharusnya mengintegrasikan pengetahuan baru ke dalam korpus ajaran Islam, dengan menghilangkan, merubah, menafsirkan kembali dan mengadopsi komonenkomponennya sebagaimana pandangan Islam dan ajaran nilai-nilainya.

Bertolak belakang dengan pandangan para penganjur Islamisasi ilmu, Kuntowidjoyo (2006: 50-55), mengartikan integralisasi ilmu atau ilmu-ilmu integralistik adalah produk bersama seluruh manusia beriman. Kuntowidjoyo, mengartikan integrasi ilmu dan agama sebagai dediferensiasi (rujuk kembali), atau penyatuan kembali agama dengan sektor-sektor kehidupan lain termasuk agama dan ilmu. Agama menyediakan tolok ukur kebenaran ilmu (benar, salah), bagaimana ilmu diproduksi (baik, buruk), dan tujuan-tujuan ilmu (manfaat, merugikan). Selebihnya, adalah hak manusia untuk memikirkan dinamika internal ilmu. Ilmu yang lahir dari induk agama harus lahir menjadi ilmu yang obyektif. Artinya, suatu ilmu tidak dirasakan oleh pemeluk agama lain, non-agama dan anti agama sebagai norma, akan tetapi sebagai gejala keilmuan yang obyektif semata. Meyakini latar belakang agama yang menjadi sumber ilmu atau tidak, tidak menjadi masalah, ilmu yang berlatar belakang agama adalah ilmu yang obyektif, bukan agama yang normatif. Maka, obyektifikasi ilmu adalah dari orang beriman untuk seluruh manusia, tidak hanya untuk orang beriman saja. Dengan demikian, menurut Kunto, ilmu integralistik ialah ilmu yang menyatukan (bukan sekedar menggabungkan) wahyu Tuhan dan temuan 
pikiran manusia (ilmu-ilmu integralistik), tidak akan mengucilkan wahyu Tuhan (sekularisme) atau mengucilkan manusia (other wordly asceticism).

Bisa jadi, apa yang diharapkan M. Amin Abdullah tentang integrasi keilmuan seperti yang telah dicetuskan oleh para penganjur Islamisasi ilmu dan pengilmuan Islam (konsep Kuntowidjoyo), apabila kita sepakat jikalau integrasi itu merupakan konsep yang berbeda dengan interkoneksi. Seperti yang kita ketahui, konsep Amin berbeda dengan konsep Islamisasi ilmu atau pengilmuan Islam (Kuntowidjoyo), Amin dalam konsepnya bukan hanya berkutat dengan istilah integrasi saja, melainkan interkoneksi. Menurut Dawam Rahardjo (2013:9), Amin mengemukakan tiga pandangan mengenai hubungan antar disiplin ilmu yang berujung pada teori interkoneksitas. Teori interkoneksitasnya itu menurut Dawam, mirip dengan teori alFarabi tentang negara dan masyarakat, tetapi diterapkannya dalam entitas ilmu yang menempatkan agama atau wahyu sebagai inti atau jiwa yang menjadi titik orientasi semua disiplin ilmu yang dalam skema sarang laba-labanya, Amin letakkan di tengah-tengah sehingga terkoneksi dengan semua disiplin ilmu yang melingkarinya.

Dengan demikian, melihat pola dan model integrasi keilmuan di atas, penulis lebih cenderung terhadap model integrasi-interkoneksi keilmuan M. Amin Abdullah. Karena, model Islamisasi Ilmu hanya sekedar mengklaim dan menjudge suatu keilmuan tertentu untuk diislamkan, tanpa memberikan solusi alternatif bagi pengembangan ilmu pengetahuan. Sementara itu, model Obyektivikasi Ilmu masih bersumberkan pada aspek epistemologi tertentu (nalar bayani), walaupun di satu sisi menjadi obyektif. Di sini, penulis lebih sepakat pada Integrasi-Interkoneksi keilmuan, karena dalam paradigma epistemologi demikian selain mengintegrasikan ilmu-ilmu agama dan umum, juga masih mempertahankan partikularitas atau keunikan keilmuan masing-masing. Oleh karena itu, penulis akan menggunakan pendekatan hermeneutika sebagai salah satu bagian dari ilmu-ilmu umum dalam menganalisis model pendidikan Agama Islam yang berbasis pada teks (ilmu agama) yang juga diintegrasikan dengan Pendidikan Kewarganegaraan di Sekolah Dasar. 


\section{Pendidikan Agama Berwawasan Kebangsaan Bagi Sekolah Dasar: Integrasi Pendidikan Agama dengan Pendidikan Kewarganegaraan}

Ketika moral bangsa ini rendah, yang kerap kali menjadi kambing hitam permasalahan adalah pendidikan Agama dan pendidikan kewarganegaraan (Pkn). Seiring berjalannya reformasi, fenomena ini tidak sepenuhnya hilang. Karena setelah sekian lama reformasi bergulir, moral bangsa ini masih jauh yang diharapkan. Kasus pelajar yang meluapkan kegembiraan pasca pengumuman kelulusan dengan cara corat-coret, bergerombol lalu menghadang bis, merupakan fakta kecil yang tak dapat dipungkiri. Belum lagi fakta kekerasan, korupsi, pembunuhan yang menghiasi pemberitaan di berbagai media. Dengan demikian, semakin lengkap untuk menjadikan Pkn dan pendidikan agama sebagai penyebabnya

Menciptakan masyarakat yang bermoral tinggi (civil society) seperti yang dicita-citakan oleh Pkn bukanlah hal yang mudah. Apalagi ketika dihadapkan pada kenyataan bangsa yang juga mengalami krisis kepemimpinan. Untuk menjawab tantangan tersebut, diperlukan berbagai upaya strategis lagi sistematis serta didukung oleh berbagai komponen di negeri ini. Salah satu upaya yang diperlukan adalah melakukan kajian ulang terhadap seluruh aspek pada Pkn dan pendidikan Agama tersebut.

Walau pernah mengalami penyalahgunaan dari penguasa pada masa orde baru, tetap harus diakui bahwa tidak ada yang salah pada tujuan Pkn dan pendidikan agama. Kehadiran Pkn dan pendidikan agama sama-sama bertujuan untuk menciptakan tatanan masyarakat yang bermoral tinggi, dalam bahasa agama disebut masyarakat yang berakhlaqul karimah. Kesemaan tujuan tersebut dapat dengan mudah kita temukan dari poin-poin ajaran Pkn dan pendidikan agama. Ambil contoh misalnya pada Pkn. Pada Pkn kita menemukan poin-poin ajaran seperti saling menghormati, jujur, bekerjasama, tata aturan, kesadaran terhadap hak dan kewajiban. Pada pendidikan agama poin-poin tersebut juga bisa dipastikan adanya. Perbedaanya 
hanya pada konteks. Konteks Pkn adalah individu dalam negara, sedangkan konteks pendidikan agama individu sebagai makhluk di atas muka bumi yang di dalamnya pastilah terdapat negara sebagai ruang aktualisasi. Dengan demikian, melakukan integrasi Pkn dengan pendidikan agama bukanlah suatu yang mengada-ada atau diada-adakan. Tetapi untuk menegaskan bahwa pesan atau yang diajarkan Pkn merupakan upaya negara dalam mengkontekskan ajaran luhur agama ke dalam kehidupan masyarakat dan bernegara.

Atas dasar persoalan tersebut, maka pendidikan agama sudah saatnya untuk tidak bisa berdiri sendiri, demikian juga Pkn. Keduanya harus terintegrasi untuk bersama-sama memecahkan problematika yang dihadapi bangsa. Dalam pendidikan Agama Islam, peta kompetensi pemebelajaran Agama Islam meliputi lima aspek, yakni :

1. Aspek Al-Quran

2. Aspek Keimanan

3. Aspek Akhlak

4. Aspek Fikih/Ibadah

5. Aspek Tarikh/Sejarah

Kelima aspek tersebut dalam pembelajaran konvensional dijalankan (diajarkan) secara terpisah, sehingga kering makna dan kurang manfaat. Agar kenyataan di atas berubah menjadi sarat makna dan bermanfaat untuk kehidupan siswa dalam menjalani hidup dan kehidupannya sebagai warga negara yang diharapkan dikemudian hari (perspektif siswa), maka guru agama harus memahami betul karakter dan kenyataan hidup yang dihadapi oleh siswanya untuk kemudian diambil sebagai tema belajar di dalam kelas.(Imam Tolkhah 2011: 79 - 110)

Di sini, penulis menawarkan dua konsep berpikir dan bertindak bagi siswa Sekolah Dasar dalam menghadapi kenyataan hidup, baik itu kehidupan sehari-hari siswa maupun kehidupan yang lebih luas, dengan demikian konsep berpikir dan bertindak bagi siswa terdiri dari dua hal yaitu konsep berpikir dan bertindak secara 
global dan lokal. Siswa harus mampu berpikir dan bertindak secara global dan lokal, namun diperlukan bantuan dan arahan dari seorang guru untuk mewujudkannya. Konsep berpikir dan bertindak secara global dan lokal akan dikaitkan dengan Pendidikan Kewarganegaraan (Pkn) dan pendidikan Agama Islam yang meliputi lima aspek sekaligus yaitu Al-Quran, Aqidah, Akhlak, Fikih, dan Sejarah.

Konsep berpikir dan bertindak secara lokal dapat diartikan sebagai proses mencermati dan menjalani kehidupan sehari-hari siswa, baik itu di keluarga, sekolah dan masyarakat. Dikarenakan kehidupan seorang siswa, tidak lain dan tidak bukan, selalu berada di dalam wilayah tersebut. Aspek kehidupan keluarga menjadi sangat urgen untuk membentuk kepribadian siswa mulai dari dasar. Pendidikan dalam keluarga merupakan pendidikan yang amat efektif dan aman. Anak kecil dapat melakukan proses pendidikan dalam keluarga dengan aman dan nyaman.. Pendidikan dalam rumah juga lebih terhormat dan berwibawa.(Moh Roqib 2009: 123) Sedangkan di sekolah bukan hanya sekedar membentuk tetapi sudah mulai untuk mengembangkan, dan di masyarakat merupakan tindakan nyata bagi siswa untuk mempraktikan apa yang sudah dibentuk dan dikembangkan baik itu di keluarga maupun di sekolah.

Dalam pembelajaran Agama di sekolah dasar hendaknya seorang guru mulai menerapkan pembelajaran terintegrasi baik itu di keluarga, sekolah dan masyarakat. Artinya, ketiga hal tersebut diolah sedemikian rupa oleh guru sehingga dapat diintegrasikan dalam pembelajaran pendidikan Agama. Bagi pendidikan agama di sekolah dasar, tentunya pola integrasi antara keluarga, sekolah, dan masyarakat di mulai dari aspek-aspek yang sederhana dan menjadi prinsip bagi seseorang peserta didik dalam kehidupan sehari-hari. Misalnya saja adalah aspek kejujuran, toleransi, disiplin, kerja keras, kreatif, mandiri, dan lain sebagainya. Tentu saja, aspek-aspek demikian bukan berarti tidak ada sama sekali dalam Agama, khususnya pada pendidikan Agama. Demikian juga dalam Pkn, aspek-aspek tersebut sudah tercantum dalam berbagai materinya khususnya mengenai pendidikan kharakter. Karena 
mengingat Pkn merupakan suatu mata pelajaran yang berfungsi sebagai sarana pembinaan akhlak masyarakat dalam membangun bangsa menjadi lebih bermoral dan bermartabat.

Jelas di sini ada titik temu antara pendidikan Agama dan Pkn, yaitu pembinaan akhlak. Keduanya seharusnya saling bersinergi, saling mengisi dan bukan justru malah saling terpisah dan memprioritaskan ke"aku"an masing-masing mata pelajaran. Aspek-aspek normatif tersebut (aspek kejujuran, toleransi, disiplin, kerja keras, kreatif, mandiri, dan lain sebagainya) setidaknya harus menjadi topik pembelajaran pendidikan Agama. Sebagai misal kejujuran, dalam pembelajaran Agama memang sudah ditekankan berkali-kali dan berulang-ulang mengenai aspek kejujuran ini. Bahkan, dikutip ayat-ayat di sana-sini sebagai landasan normatif. Namun, siswa masih saja tetap melakukan (dalam arti melanggar) untuk berlaku yang tidak jujur. Di dalam Pkn pun dirasa demikian, materi pembelajaran tentang kejujuran sudah berkali-kali diterangkan tetapi tetap saja masih belum mengena di hati dan tindakan siswa.

Dengan demikian, pendidikan Agama dan Pkn harus bersama-sama bekerjasama untuk mengemas materi kejujuran ini untuk selanjutnya diterapkan kepada siswa, tentunya, sekali lagi peran guru sangat dibutuhkan dalam pengintegrasian ini. Pembelajaran kejujuran dalam pendidikan Agama yang teringrasi dengan Pkn ini, bukan hanya berhenti pada wilayah normatif, akan tetapi juga memasuki wilayah historis yakni penerapannya di sekolah, keluarga dan masyarakat. Dalam Pkn, pendidikan kharakter menjadi misi utama dalam tujuan pembelajaran. Apabila aspek kejujuran ini menjadi poin penting bagi pendidikan karakter, maka mata pelajaran Pkn tentunya harus lebih mengupayakan aspek internalisasi kejujuran ini dalam diri peserta didik.

Indikator kejujuran dalam mata pelajaran Pkn, misalnya sebagai berikut : menepati janji, berkata dan bertindak secara benar sesuai degan fakta/ tidak bohong, bekerja berdasarkan kewenangan yang dimiliki, dan berkemauan untuk memelihara 
dan mengekspresikan kebenaran. Indikator-indikator tersebut hendaknya diintegrasikan dan diinterkoneksikan dengan pendidikan Agama Islam, baik itu pada aspek aqidah, Al-Quran, akhlak, fikih, dan sejarah sekaligus.

Apabila menggunakan pendekatan hermeneutik sebagai alat analisis teks, maka akan diperoleh penjelasan tentang tiga entitas yang saling berdialektika sekaligus baik itu pada wilayah teks, konteks, maupun kontekstualisasi. Dalam hermeneutika makna teks yang dimaksud adalah makna teks secara morfologis, leksikologis, dan sintaksis. Sedangkan makna konteks adalah memaknai dari siapa teks itu berasal, untuk tujuan apa, dalam kondisi apa, dan bagaimana kondisi pengarangnya ketika teks tersebut disusun. Sedangkan kontekstualisasi adalah melakukan suatu produksi makna baru dari pemahaman terdahulu. (Fakhruddin Faiz $2005: 8-9)$

Di sini, penulis hendak memodifikasi di sana-sini pengertian teks, konteks, dan kontekstualisasi. Teks di sini penulis artikan sebagai Pendidikan Agama Islam, karena PAI yang terdiri dari Kalam, Akhlak, Tafsir, Fiqh, dan Tarikh berlandaskan pada epistemologi bayani. Sebagaimana yang diungkapkan oleh Abed al-Jabiri, "Pemikiran bayani ini adalah semua pemikiran yang diproduksi oleh peradaban Arab Islam yaitu bagi orang-orang yang masih memandang dan menggunakan metode berpikir terhadap pengetahuan yang mengkristal dan diabadikan dalam ilmu-ilmu Arab secara istidlal dan eksklusif yaitu nahwu, fikih, kalam, dan balaghah".(Abed alJabiri $1991: 13$ )

Sedangkan konteks, diartikan sebagai mata pelajaran umum (kewarganegaraan) seperti dalam tulisan ini adalah Pkn. Sebagaimana yang diungkapkan sebelumnya bahwa konteks itu merupakan makna yang didapat dari kondisi ataupun keadaan. Jadi, karena mata pelajaran umum entah itu dari natural sains dan sosial-humanities sains berasal dari kondisi atau keadaan yang berada di alam, sosial, maupun manusia, dan Pkn sendiri konteksnya ialah individu dalam negara, atau bisa disebut sebagai kondisi, keadaan, realitas individu dalam negara. 
Sedangkan kontekstualisasi adalah integrasi antara teks dan konteks sehingga dapat bermanfaat dan selalu relevan dalam kondisi kekinian, khususnya dalam diri peserta didik baik di sekolah, keluarga dan masyarakat.

Pendidikan Agama di sini adalah sebagai teks yang diwakili oleh aqidah, AlQuran, akhlak, fikih, dan tarikh. Sedangkan konteksnya adalah Indikator kejujuran dalam mata pelajaran Pkn yaitu menepati janji, berkata dan bertindak secara benar sesuai degan fakta/ tidak bohong, bekerja berdasarkan kewenangan yang dimiliki, dan berkemauan untuk memelihara dan mengekspresikan kebenaran. Konteks di sini juga dapat diartikan sebagai perilaku tokoh, atau contoh tindakan dan perilaku dari seseorang yang dianggap otoritatif. Sedangkan kontekstualisasinya adalah bagaimana penerapannya di sekolah, keluarga dan masyarakat. Jadi, di sini ada tiga yang sudah terwakili sekaligus yaitu reader (seorang guru), teks (pendidikan agama), dan audience (sekolah, keluarga, dan masyarakat).

Pendidikan Agama yang terdiri dari aqidah, Al-Quran, akhlak, fikih, dan sejarah harus melihat dan meninjau aspek kejujuran yang indikatornya sebagaimana disebutkan di atas. Dalam aqidah misalnya, materi tentang ketauhidan, hendaknya harus diintegrasikan dengan nilai kejujuran. Seorang peserta didik harus dijelaskan dan ditanamkan sedemikian rupa, pembahasan tentang aqidah yang bukan hanya bersifat normatif dan terkesan abstrak, akan tetapi pembelajaran yang bersifat historis dalam kehidupan peserta didik. Sebagai misal, peserta didik tentunya memahami betul sifat-sifat Tuhan bahwa Tuhan Maha Tahu, Tuhan Maha Pengasih dan Penyayang, Tuhan Maha Perkasa, dan lain sebagainya. Namun seorang guru tidak hanya berhenti pada wilayah itu saja, melainkan juga harus bisa mengaitkan hal-hal normatif tersebut dengan aspek kejujuran. Misalnya, Tuhan Maha Tahu siapa hamba-Nya yang berkata benar dan tidak, Tuhan Maha Pengasih dan Penyayang bagi hambanya yang selalu berbuat baik dan berkata benar, dan lain sebagainya, dan selanjutnya seorang guru perlu juga mengaitkan aspek-aspek normatif tersebut ke wilayah sekolah, keluarga, dan masyarakat. 
Di sekolah misalnya, peserta didik harus diberi pengertian bahwa mencontek itu adalah sesuatu perbuatan yang tidak jujur, oleh karena itu Tuhan Maha Tahu siapa saja dari peserta didik tersebut yang mencontek. Karena Tuhan Maha Tahu, berarti setiap perbuatan yang dilakukan pasti akan mendapatkan balasannya masing-masing, yang baik dan jujur akan mendapat pahala, sedangkan yang tidak baik dan mencontek (tidak jujur) berarti akan mendapat dosa. Namun, seorang guru tetap harus menekankan sisi-sisi yang positif dan baik terhadap peserta didik, misalnya, Tuhan itu Maha Pengasih dan Penyayang bagi siswa-siswi yang memang berniat baik, berlaku baik, dan berkata baik dan jujur, pasti mereka akan mendapat pahala dan Rahmat Tuhan yang tak terbatas.

Selanjutnya, seorang guru juga harus menjelaskan prinsip-prinsip demikian di rumah dan masyarakat. Bagaimana peserta didik itu harus bersikap jujur dengan orang tua, saudara, kakak-adik, kakek-nenek, dan lain sebagainya. Begitu pula di masyarakat bagaimana peserta didik itu dapat bertindak jujur terhadap tetangganya, teman sepermainannya, dan lain sebagainya. Dan yang paling penting semua kegiatan tersebut harus dilandasi dengan semangat ketauhidan. Pemahaman demikian juga tidak hanya berhenti dalam aspek aqidah saja, tetapi juga berlaku bagi aspek-aspek pendidikan Agama yang lain, seperti Al-Quran, fikih, sejarah, dan akhlak. Jadi, semua aspek-aspek tersebut (Aqidah, Al-Quran, fikih, sejarah, dan akhlak) itu saling terintegrasi dan terinterkoneksi dengan aspek kejujuran.

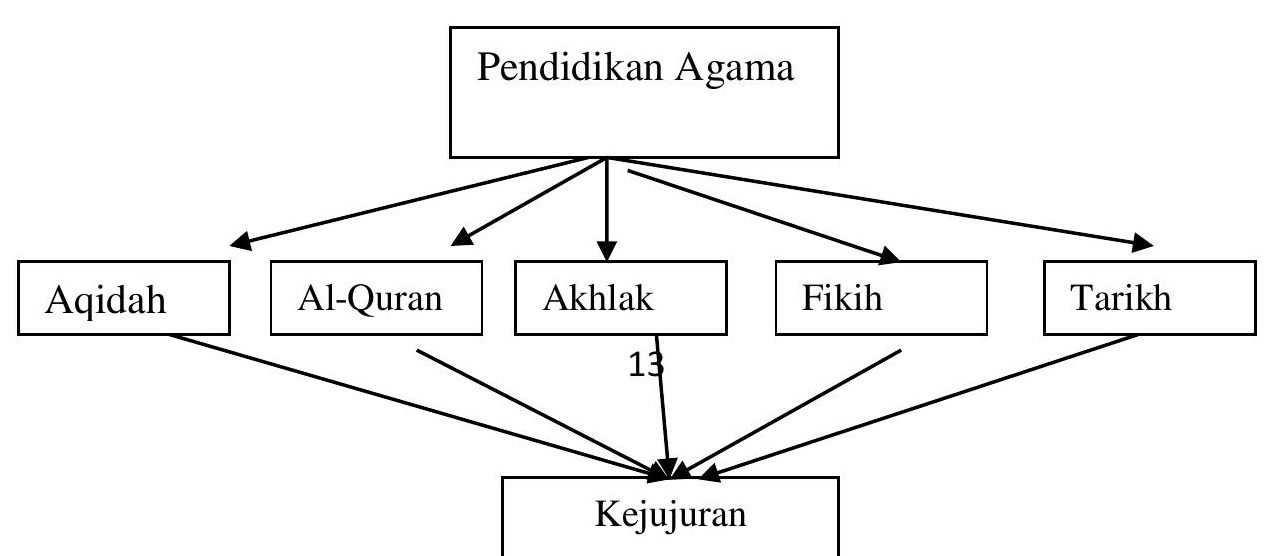


Konsep berpikir dan bertindak secara global dapat diartikan sebagai pandangan dan tindakan bagi peserta didik dalam konteks yang lebih luas. Di sini, konsep pendidikan Agama terintegrasi dengan Pkn harus memiliki muatan-muatan materi yang mencakup konteks berbangsa dan bernegara. Muatan-muatan materinya harus kontekstual yang ditandai dengan problem-problem kekinian yang dihadapi bangsa. Sebenarnya, Pkn telah menanamkan banyak nilai seperti nilai kesadaran, bela negara, penghargaan terhadap hak asasi manusia, kemajemukan bangsa, pelestarian lingkungan hidup, tanggung jawab sosial, ketaatan pada hukum, ketaatan membayar pajak, serta sikap dan perilaku anti korupsi, kolusi dan nepotisme.

Nilai-nilai di atas menurut penulis merupakan cerminan pola berpikir global seperti penghargaan terhadap hak asasi manusia, kemajemukan bangsa, pelestarian lingkungan hidup, tanggung jawab sosial, serta sikap dan perilaku anti korupsi, kolusi, dan nepotisme. Beberapa hal yang perlu diperhatikan bagi peserta didik untuk bisa berpikir global ialah mereka harus berkepribadian keindonesiaan. Ini penting bagi peserta didik, oleh karena itu mereka dituntut untuk memiliki rasa hormat, bersikap kritis, mengutamakan dialog dan diskusi, memiliki keterbukaan dan pandangan yang luas dan visioner, bersikap adil, mencintai bangsa dan sesama manusia. 
Mengenai model pendidikan Agama terintegrasi dengan Pkn yang berwawasan global bagi pendidikan Dasar, memang masih terlalu tinggi muatan materinya. Oleh karena itu, guru dalam menyampaikan materi yang berwawasan global paling tidak menyesuaikan dengan tingkat dan pola berpikir siswa sekolah dasar. Walaupun tema-tema yang disajikan itu bernuansa luas dan tinggi, tetapi paling tidak seorang guru harus mengemas sedemikian rupa bagaimana agar tematema yang berat dan tinggi tersebut dapat dijelaskan dan dicerna oleh para siswa sekolah dasar. Sebagai misal, apabila seorang guru sudah memberikan dan memahamkan kepada peserta didik tentang aspek-aspek berpikir dan bertindak secara lokal, seperti kejujuran sebagaimana disinggung di atas, paling tidak seorang guru juga mulai untuk menaikkan sedikit tingkatan kejujuran tersebut kepada level pencegahan korupsi, kolusi, dan nepotisme.

Dalam hal ini, peserta didik tidak dimaknai harus paham dan mengerti betul apa itu korupsi, kolusi, dan nepotisme beserta seluk beluknya yang mungkin bagi tingkat pemahaman siswa sekolah dasar amat begitu kompleks. Tetapi paling tidak, seorang guru harus menjelaskan (sesuai dengan tingkat berpikir mereka) apa itu korupsi, kolusi dan nepotisme yang dikaitkan dengan kejujuran. Tentunya, pembelajaran ini juga harus dikaitkan dengan realitas kehidupan sehari-hari peserta didik. Misalnya, peserta didik dilarang untuk berbohong kepada orang tua, dilarang mengambil barang yang bukan miliknya, berkata benar dan apa adanya terhadap guru, dan ataupun teman sebayanya dan lain-lain.

Pola pendidikan Agama terintegrasi dengan Pkn secara global sama penjelasannya dengan pendidikan Agama terintegrasi Pkn secara lokal. Hanya yang berbeda adalah muatan materinya dan modelnya. Pendidikan Agama (sebagai teks), perbuatan korupsi, kolusi, dan nepotisme (sebagai konteks), dan pemecahan masalah terhadap problem-problem kekinian tersebut melalui pendidikan Agama (kontekstualisasi). Di sini, seorang guru (reader), harus bisa mengolah, menjelaskan, menafsirkan sedemikian rupa terhadap pendidikan Agama (teks), sehingga PAI bukan 
hanya berada pada dataran normatif saja, melainkan dapat membumi dan memberikan maslahat bagi kehidupan umat khususnya peserta didik (audience).

\section{Pendidikan Agama Multikultural Bagi Sekolah Dasar: Pengembangan Pola Berpikir Global dan Lokal}

Dalam kaitannya dengan pembahasan sebelumnya, tulisan kali ini akan menyinggung secara khusus mengenai pendidikan multikultural yang merupakan bagian dari salah satu pandangan atau wawasan kebangsaan. Dalam Pkn, multikultural ini masuk kepada nilai-nilai yang menghargai kemajemukan bangsa. Apabila di atas telah dibahas mengenai pola berpikir global dan lokal yang mengarah pada aspek kejujuran dan korupsi, kolusi, dan nepotisme yang menjadi bagian nilai dari mata pelajaran Pkn yang kemudian diintegrasikan dalam pendidikan Agama Islam melalui pendekatan integrasi keilmuan antara ilmu agama (yang diwakili pendidikan Agama) dengan hermeneutika (yang mewakili ilmu-ilmu sosialhumaniora). Maka, dalam pembahasan ini secara khusus menyinggung pendidikan Agama berwawasan multikultural dalam lingkup lokal dan global dengan menggunakan pendekatan yang sama.

Terlebih dahulu, akan diidentifikasi arti multikulturalisme dan pluralisme agar diperoleh perbedaan yang jelas di antara keduanya. Pluralisme dalam pandangan Seyyed Hossein Nasr (1994: 15) dijelaskan sebagai berikut, Nasr menjelaskan tentang The religion (sang agama) dan a religion ( suatu agama). Setiap wahyu agama adalah Sang Agama itu (The Religion) dan suatu agama (a religion), The religion ( sang agama itu) dalam sebanyak itu berisi dalam Kebenaran itu sendiri dan berarti mencapai Kebenaran itu, a religion (suatu agama) karena menekankan aspek partikular dari Kebenaran sesuai kebutuhan spiritual dan psikologi kemanusiaan untuk siapa itu ditakdirkan dan siapa ditujukan. Sementara, menurut Farid Essack (1998: xii), pluralisme merupakan pengakuan dan penerimaan, bukan hanya toleransi terhadap yang lain (otherness) dan perbedaan (diversity) dalam dirinya dan yang 
lainnya. Dalam konteks agama, pluralisme berarti penerimaan terhadap berbagai jalan yang berbeda dari respon menuju kepada Yang Transenden. Sementara itu Diana Eck mengartikan Pluralisme bukanlah relativisme. Perspektif pluralisme yang benar akan berkomitmen untuk mengikat setiap perbedaan yang kita temui, untuk memperoleh pengertian mendalam dari masing-masing komitmen yang lain. (Omid Shafi 2003: 252)

Sementara itu, Istilah multikulturalisme dalam Collins Dictionary of Sociology (1991) dijelaskan, bahwa istilah ini mempunyai pengertian "pengakuan dan promosi tentang keanekaragaman budaya berupa keistimewaan dari beberapa masyarakat. Sebagai perlawanan terhadap kecenderungan masyarakat modern untuk melakukan unifikasi dan universalisasi budaya, multikulturalisme sekaligus merayakan dan mencoba untuk melindungi keanekaragaman budaya. Tegasnya, multikulturalisme adalah sebuah pengakuan yang dibangun oleh kesadaran individu maupun kelompok atas penghargaannya terhadap eksistensi nilai-nilai budaya, falsafah, adat-istiadat, gaya hidup, bahasa, pandangan hidup dan idiologi masyarakat tertentu. (Andy Dermawan 2009: 68)

Multikulturalisme melibatkan sebuah pemahaman, apresiasi, dan nilai-nilai kebudayaan seseorang dan sebuah penghormatan akan keingintahuan terhadap kebudayaan etnis lainnya. Multikulturalisme menyangkut sebuah nilai kebudayaankebudayaan lainnya, bukan di dalam pengertian menyetujui semua aspek kebudayaan-kebudayaan tersebut, tetapi berusaha melihat bagaimana suatu kebudayaan tertentu dapat mengungkapkan nilai kepada para anggotanya. (Larry May 1998: 15). Jadi, Inti dari multikulturalisme adalah toleransi, saling menghargai, memahami, dan menghormati antar suku, bangsa, budaya, dan agama yang berbeda.

James Banks (1994) menjelaskan, bahwa pendidikan multikultural memiliki beberapa dimensi yang saling berkaitan satu dengan lainnya, yaitu : Pertama, content integration, yaitu mengintegrasikan berbagai budaya dan kelompok untuk mengilustrasikan konsep mendasar, generalisasi dan teori dalam mata pelajaran. 
Kedua, the knowledge construction process, yaitu membawa siswa untuk memahami implikasi budaya kedalam sebuah mata pelajaran. Ketiga, an equity paedagogy, yaitu menyesuaikan metode pengajaran dengan cara belajar siswa dalam rangka memfasilitasi prestasi akademik siswa yang beragam baik dari segi, budaya (culture) ataupun sosial (social). Keempat, prejudice reduction, yaitu mengidentifikasi karakteristik ras siswa dan menentukan metode pengajaran mereka. Kemudian melatih kelompok untuk berpartisipasi dalam kegiatan olah raga, berinteraksi dengan seluruh staff, dan siswa yang berbeda etnis dan ras dalam upaya menciptakan budaya akademik yang toleran dan inklusif. (Choirul Mahfud 2010: 177)

Pendidikan dengan wawasan multikultural dalam rumusan James Bank merupakan konsep, idea tau falsafah sebagai suatu rangkaian kepercayaan (set of believe) dan penjelasan yang mengakui dan menilai pentingnya keragaman budaya dan etnis di dalam membentuk gaya hidup, pengalaman sosial, identitas pribadi, kesempatan-kesempatan pendidikan dari individu, kelompok maupun Negara.

Para pakar pendidikan mengidentifikasi tiga lapis diskursus pendidikan multikultual antara lain masalah kebudayaan, kebiasaan-kebiasaan, tradisi, pola-pola kelakuan yang hidup dalam masyarakat, kegiatan atau kemajuan tertentu (achieviement) dari kelompok-kelompok dalam masyarakat yang merupakan identitas dan melekat dalam kelompok. :

a. Masalah kebudayaan : dalam hal ini menyangkut masalah-masalah mengenai identitas budaya suatu kelompok masyarakat atau suku. Bagaimana hubungan antara kebudayaan dan kekuasaan dalam masyarakat sehubungan dengan konsep kesetaraan di masyarakat.

b. Kebiasaan-kebiasaan, tradisi, pola-pola kelakuan yang hidup dalam masyarakat; bagaimana praktik-praktik dalam kehidupan sehari-hari.

c. Kegiatan atau kemajuan tertentu (achievement) dari kelompok-kelompok dalam masyarakat yang merupakan identitas kelompok; apakah ditemukan prestasi atau 
kharakteristik masyarakat yang dapat diterima dan dapat dijadikan sebagai model dalam kehidupan di masyarakat.

Tiga lapis konsep pendidikan multikultural tersebut menyangkut persoalanpersoalan mendasar sebagai berikut :

a. Perlu adanya konsep yang jelas mengenai kebudayaan

b. Wacana tentang peran pendidikan dalam membentuk identitas budaya dan identitas bangsa Indonesia.

c. Tentang bagaimana hak orang tua dalam menentukan pendidikan bagi anaknya.

d. Tentang hakikat pluralisme yang berarti pengakuan terhadap kelompok-kelompok minoritas di masyarakat.

e. Tidak kurang pentingnya pula dipermasalahkan nilai-nilai mana yang akan dipertimbangkan dalam masyarakat majemuk atau pluralistic society. (Masngud 2010: 170-171)

Dengan demikian, dalam pembahasan kali ini, penulis hendak menampilkan pendidikan multikultural bagi sekolah dasar berwawasan global dan lokal. Tentunya sekali lagi, karena multikultural ini juga merupakan bagian dari komponen pendidikan kewarganeraan, maka integrasi pendidikan Agama dengan Pkn ini niscaya diperlukan dalam pengembangan Pendidikan Agama Integratif. Dalam konteks lokal sekali lagi diartikan sebagai proses mencermati dan menjalani kehidupan sehari-hari siswa, baik itu di keluarga, sekolah dan masyarakat. Berarti pendidikan multicultural bagi sekolah dasar dalam konteks lokal harus mencermati ketiga wilayah tersebut yaitu keluarga, sekolah, dan masyarakat.

Pendidik dapat mengintegrasikan konsep multikulturalisme ini ke dalam muatan materi pendidikan Agama Islam (teks) yang di dalamnya terdapat tujuan dari pembelajaran Pkn seperti toleransi, saling menghargai, memahami, dan menghormati (konteks), lalu bagaimana kontekstualisasinya di dalam keluarga, sekolah, dan masyarakat. Di sini, seorang guru juga harus memiliki kreativitas dan pemahaman yang luas, mengenai nilai-nilai toleransi ditinjau dari aspek Aqidah, Akhlak, Al- 
Quran-Hadist, Fiqh, dan Tarikh. Misalnya, dalam Al-Quran seorang guru dapat memberikan penjelasan tentang pentingnya toleransi dari ayat-ayat yang telah dikutip oleh guru, tentunya ayat-ayat tentang toleransi, seperti Qs. Al-Hujurat: 13. Dengan mengambil subtansi ayat tersebut yaitu saling menghargai dan menghormati perbedaan-perbedaan yang ada, maka guru dapat memberikan contoh yang lebih sederhana dalam konteks keluarga, yaitu seorang guru harus memberi pengertian, pelajaran, dan wawasan terhadap peserta didik mengenai pentingnya saling menghargai dan menghormati orang-orang terdekat peserta didik dalam keluarga, misalnya orang yang dituakan, seperti kakek, nenek, ayah, ibu, kakak, dan lain sebagainya. Dalam konteks sekolah, seorang guru juga harus memberikan wawasan, pengertian dan pelajaran terhadap peserta didik untuk saling menghormati dan menghargai perbedaan-perbedaan yang dimiliki oleh setiap peserta didik, misalnya perbedaan pendapat, perbedaan prestasi, perbedaan latar belakang etnisnya, agamanya, maupun budayanya. Dalam masyarakat pun demikian, misalnya menghargai dan menghormati keyakinan orang lain dengan tidak mengganggunya dan menodainya, memberikan kesempatan untuk beribadah, menghormati orang yang sedang melaksanakan hari rayanya, dan lain sebagainya.

Dalam konteks global, peserta didik dapat menilai konflik yang terjadi di tanah air, baik itu konflik intern dan ekstern antar umat beragama. Namun dalam hal ini, peserta didik harus mendapat bimbingan guru. Guru dapat mengemas dengan menarik dan sesuai dengan tingkat berpikir mereka, tentang peristiwa-peristiwa aktual yang berhubungan dengan multikulturalisme ini. Misalnya, kekerasan antar suku, kelompok, dan agama, topik ini menjadi bahan kajian menarik. Guru dapat mengolah dan mengemas bagaimana topik tersebut bisa dipahami secara mudah dan benar-benar meresap dalam diri peserta didik. Misalnya, seorang guru dapat menjelaskan bahwa perang akan berdampak pada pertumpahan darah yang dapat menimbulkan disintegrasi bangsa dan perang bukanlah satu-satunya solusi dalam menyelesaikan masalah. Oleh sebab itu, guru harus menekankan kepada siswa 
bahwa, sesungguhnya Tuhan dalam setiap agama tidak menginginkan jalan kekerasan, akan tetapi jalan perdamaian. Hal ini dapat dibuktikan dengan banyaknya ajaran-ajaran moral dalam setiap agama. Sehingga, siswa akan lebih paham bahwa perang bukanlah satu-satunya jalan untuk menyelesaikan masalah, sekaligus perang berarti bertentangan dengan perintah Tuhan untuk menciptakan perdamaian dan kerukunan antar umat manusia. (Y.M. Zaka 2012: 188)

Hal ini secara otomatis akan memberikan pandangan positif terhadap peserta didik terhadap orang yang menganut keyakinan yang berbeda dengan dirinya. Apabila sudah tertanam sikap positif maka peserta didik tidak akan canggung lagi dan bersikap terbuka terhadap yang lain serta memiliki rasa toleransi yang tinggi dengan misalnya mengajak dialog atau diskusi dan bersikap adil terhadap mereka, dengan demikian peserta didik akan tertanam dengan kuat rasa cinta terhadap bangsanya dan sesama manusia. Mereka akan memandang bahwa perbedaan itu anugrah Tuhan yang paling indah dan harus turut serta dijaga agar tidak terjadi kekacauan (konflik). Di sini, sebenarnya peserta didik sudah mentaati dan menerima apa yang sudah ditetapkan Tuhan yaitu keberagaman atau pluralitas itu sendiri.

\section{Simpulan}

Terjadi kesenjangan yang tajam antara idealisme dan realism, dassein dan dassolen, teori dan praktik. Mungkin begitu secara faktual dalam kehidupan kontemporer ini. Dalam bahasa filsafat ilmu, tidak adanya korespondensi antara yang "seharusnya" dan "senyatanya". Praktik kehidupan yang hari demi hari semakin jauh dari nilai-nilai atau semangat normativitas ajaran dirasa semakin menjadi-jadi, dan bahkan tidak berlebihan kalau dikatakan semakin kronis, sehingga memerlukan penanganan yang serius. Krisis moralitas yang terjadi pada bangsa menjadi semakin kuat dengan didukung adanya nilai-nilai budaya yang destruktif terhadap moralitas anak bangsa. 
Dengan demikian diperlukan solusi yang tepat dalam mengatasi kesenjangan di atas. Salah satu solusinya ialah menerapkan pola integrasi keilmuan. Integrasi antara agama dan ilmu menjadi kerangka filosofis yang penting bagi terkonstruknya paradigma yang baru dan sophisticated dalam memandang problem kontemporer. Paradigma ini diharapkan akan memberikan nuansa baru dan segar dalam upaya memecahkan problem-problem aktual. Proyek integrasi ini dinilai tepat apabila diaplikasikan dalam konteks pendidikan agama. Karena pendidikan (khususnya pendidikan agama) merupakan upaya atau proses untuk memanusiakan manusia sehingga menjadi manusia yang beriman, bertaqwa, serta bermoral dan bermartabat.

Salah satu mata pelajaran yang tepat dalam upaya merekonstruksi pendidikan agama berparadigma integrasi ialah pendidikan kewarganegaraan. Seperti yang diketahui Pkn ini memiliki problem yang sama dengan pendidikan agama, yaitu problem kesenjangan. Di satu sisi, dua mata pelajaran ini mengajarkan dan menanamkan model ideal bagi peserta didik untuk menjadi manusia yang beriman, bertaqwa dan bermoral, bermartabat. Tetapi pada sisi lainnya, realitas tidak seindah apa yang diharapkan. Imoralitas, kekerasan, pelecehan, dan perilaku-perilaku peyoratif lainnya yang semakin meningkat. Untuk itu, dalam menghadapi problemproblem tersebut pendidikan agama dan pendidikan kewarganegaraan sudah saatnya untuk saling mengisi, bekerjasama, berdialektika dan berdialog dalam mengatasi problematika umat.

Upaya integrasi pendidikan kewarganegaraan dengan pendidikan agama ini dibantu dengan menggunakan pendekatan ilmu-ilmu sekular-modern seperti hermeneutika sebagai pendekatan dalam menganalisis proses integrasi dua mata pelajaran tersebut. Di sini berarti ada tiga entitas yaitu pendidikan agama, pendidikan kewarganegaraan, dan hermeneutika. Ketiganya saling berdialog dan berdialektika untuk mengkonstruk pendidikan agama terintegrasi. Dalam proses dialektika itu hermeneutika menawarkan konsep triadik yaitu teks, konteks, dan kontekstualisasi. Teks di sini diartikan sebagai Pendidikan Agama Islam. Sedangkan konteks, diartikan 
sebagai mata pelajaran umum (kewarganegaraan) seperti dalam tulisan ini adalah Pkn. Sedangkan kontekstualisasi adalah integrasi antara teks dan konteks sehingga dapat bermanfaat dan selalu relevan dalam kondisi kekinian baik di negara atau bangsa (konteks global), dan khususnya dalam diri peserta didik baik di sekolah, keluarga dan masyarakat (konteks lokal).

\section{Daftar Pustaka}

Abdullah, M. Amin. (2012). Islamic Studies di Perguruan Tinggi; Pendekatan Integratif-Interkonektif. Yogyakarta: Pustaka Pelajar.

Al-Faruqi, Ismail Raji. (1982). Islamization of Knowledge: General Principles and Workplan. Maryland: International Institute of Islamic Thought.

Al-Jabiri, Mohammed Abed. (1991). Bunyah Al-Aql Al-Arabi: Dirasah Tahliliyyah Naqdiyyah li Nudûmi al-Ma'rifah fi al-Tsaqafah al-'Arabiyyah. Beirut, AlMarkaz Dirasah al-Wihdah al-'Arabiyyah.

Dermawan, Andy. (2009). Dialektika Islam dan Multikulturalisme di Indonesia: Ikhtiar Mengurai Akar Konflik.Yogyakarta: Kurnia Kalam Semesta.

Essack, Farid. (1998). Qur'an, Liberation \& Pluralism; an Islamic Perspective of Inter-religious Solidarity Against Oppression. England; One World Publications.

Faiz, Fakhruddin. (2005). Hermeneutika Al-Quran: Tema-Tema Kontroversial. Yogyakarta: ElsaqPress.

Gulen, M. Fethullah. (2006). The Essentials of the Islamic Faith. New Jersey: Light. Khaleel, Kasem. (2003). Science and Religion: What You Were Never Told. Illnoies: Knowledge House.

Kuntowidjoyo. (2006). Islam Sebagai Ilmu: Epistemologi, Metodologi dan Etika. Yogyakarta: TiaraWacana.

Mahfud, Choirul. (2010). Pendidikan multikultural.Yogyakarta:Pustaka Pelajar. Masngud dkk. (2010). Pendidikan Multikultural Pemikiran dan Upaya Implementasinya. Yogyakarta : Idea Press. 
May, Larry dkk. (1998). Applied Ethics A Multicultural Approach. New Jersey: Prentice Hall.

Nasr, Seyyed Hossein. (1994). Ideals And Realities of Islam. London; Aquarian.

Rahardjo, M. Dawam. (2013). Masa Depan Perguruan Tinggi Islam: Sumbangan Pemikiran M. Amin Abdullah.

Rolston, Holmes. (1987). Science and Religion: A Critical Survey. New York, Random House.

Roqib, Moh. (2009). Ilmu Pendidikan Islam: Pengembangan Pendidikan Integratif di Sekolah, Keluarga, dan Masyarakat. Yogyakarta: LKIS.

Safi, Omid. (2003). Progresive Muslims; on Justice, Gender and Pluralism. Oxford; One World Publications.

Shaleh, Khudori. (2012). Wacana Baru Filsafat Islam. Yogyakarta : Pustaka Pelajar.

Tholkhah, Imam (ed). (2011). Buku Pengayaan Guru PAI: Pendidikan Kewarganegaraan, Budaya \& Agama. Jakarta: Kementrian Agama RI.

Zaka, Y.M. (2012) "Esoterisme Seyyed Hossein Nasr Dan Relevansinya Dengan Pendidikan Islam Inklusif-Pluralis; Studi Filsafat Perennial”, skripsi, Fakultas Tarbiyah \& Keguruan UIN Sunan Kalijaga.

Online :

Cholisin, "Pengembangan Karakter Dalam Materi Pembelajaran Pkn", http://staff.uny.ac.id/sites/default/files/tmp/PENGEMBANGAN\%20KARAK TER\%20DALAM\%20MATERI\%20PEMBELAJARAN\%20PKn.pdf. Dalam Google.com.

Oktodwi,"Kharakteristik Pendidikan Kewarganegaraan", http://id. netlog. com/oktodwi/blog/blogid=142121, dalam Google. Com. 